\title{
Sensitivity analysis of rainfall-runoff parameters models to estimate flows
}

\author{
Fernando Yogi ${ }^{1,2}\left(\right.$ Carina Julia Pensa Correa $^{1,2} \cdot$ Emerson Martins Arruda $^{1} \cdot$ Kelly Cristina Tonello $^{1,2}$
}

Received: 30 July 2020 / Accepted: 15 December 2020 / Published online: 18 January 2021

(C) The Author(s) 2021

\begin{abstract}
Determinate the runoff of a watershed is a challenge due to the complexity of representing all "inlets" and "outlets" involved in a rainfall-runoff model. Therefore, methodologies applied for this purpose should have a good representation of the variables that most influence in this process. One of the models used to calculate the design flow is the (USDA in Urban Hydrology for Small. Technical release, no 55 (TR-55). Soil Conservation Service. Washigton, DC, http://scholar.google.com/schol ar?hl=en\&btnG=Search\&q=intitle:Urban+Hydrology+for+Small+watersheds\#1, 1986), which considers the analysis changes in soil coverage, time of concentration (tc), and recurrence period ( $T$ ). In this way, this study sought to evaluate the hydrological behavior of a watershed with an increase in soil waterproofing. These modifications were correlated with the variation of runoff coefficients $(\mathrm{CN})$, modifications of the periods of recurrence indicated by the literature, and different equations of the time of concentration. Its application was carried out in the Ribeirão do Suru watershed, Santana de Parnaíba, SP, Brazil. The CN $\{75 ; 80 ; 85 ; 90\}$ increased $3.14,5.61,10.90$ and $15.85 \%$, respectively. In the most critical situation, runoff was $15.85 \%$ higher in estimated CN. The variation of precipitation as a function of $\mathrm{T}(2,5,10,25,50,100$ and 500) and application of 11 time of concentration methods designed 132 hydrographs and flow values that were statistically treated in $\mathrm{T}$ of Student and in the Analysis of Variance (ANOVA). Except for Bransby Willians associated Cinematic Method, Dooge with Johnstone and CTH with Tsuchyia, the pairs showed degrees of correlation below 59\%. The greatest correlation was observed in Jonhstone with Dooge (90\%), followed by the Kinematic Method with the Soil Conservation Service Method (83\%) and with Dodge (74\%). As a result, it was possible to demonstrate the behavior of the SCS parameters to minimize subjectivities and revealing how each parameter impacts the flow of the watershed. Finally, the sensitivity attributed to $\mathrm{T}$ was the highest among the three analyzed.
\end{abstract}

Keywords Environmental management · Hydrographic watershed $\cdot$ Hydrological parameters $\cdot$ Image classification $\cdot$ Soil conservation service

\section{Introduction}

One of the most evident conflicts in a metropolis is land use. High population density and lack of appropriate infrastructures often result in soil sealing and settlements in hazard areas. This scenario is responsible for significant changes in runoff, which may impact drainage systems and

Fernando Yogi

fyogi@hotmail.com

1 Federal University of São Carlos (UFSCar), Rod. João Leme dos Santos, km 110, Sorocaba, SP 18072-058, Brazil

2 Research Group on Hydrology in Forest Ecosystems (Hidrolef), Federal University of São Carlos (UFSCar), São Carlos, Brazil increase floods (de Aragão et al. 2017), (Bean et al. 2019). The unplanned waterproofing of urban areas is responsible for substantial changes in local hydrology, reducing the stormwater infiltration into the soil, accentuating the flow, anticipating its peak to a destination section, and increasing the volume drained over the surface (de Aragão et al. 2017), (Alves et al. 2018), (Leal and Tonello 2017).

Added to climate change, these aspects can be listed as the main environmental issues that can affect the hydrographic watershed (Shao et al. 2018), (de Silva and Valverde 2017). For management purposes, watershed approach allows the incorporation of water management in the land use and occupation policies. As presented by Zhang et al. (2018), the integrality of physical, social, economic and environmental aspects within a territorial unit is essential. Considered as an integrated planning unit, it manages to 
adhere both public administration issues and environmental protection. In this way, urban zoning, a municipal management planning tool, should contribute to the management of surface and underground water resources (Vasconcelos and Mota 2020).

Techniques to measure hydrological characteristics in a catchment area emerge constantly, and greater precision has been acquired over time. In Brazil, water resource management is hampered by the lack of hydrological information. Although this gap can be supplied by hydrological models that simulate the behavior of river watersheds (Machado et al. 2017), the challenge is to determine rainfall-runoff models that have a good representation of the parameters involved. Estimate runoff in urban watersheds, especially in areas that suffer from possible irregular occupations, is a complex and dynamic process, especially in the context of its spatial variability.

Due the uncertainties for obtaining parameters that form the rainfall-runoff models, it is important to know the real behavior of each parameter to visualize the representativeness of the components of the hydrological cycle. In this way, more accurate hydrological and physical models are obtained by limiting the parameters to more acceptable intervals, and thus, ensuring greater efficiency in terms of time and resources. This inaccuracy is also attributed to the lack of a constant survey and diagnostic uses of the occupied areas, that should accompany the fast changes in land coverage, especially in urban areas. Teston et al. (2018) point out that one of the most important parameters for sizing and checking micro and macro-drainage works is the flow associated with a critical precipitation event over the watershed.

Several models for estimating direct runoff have been developed (Alves et al. 2019; Mello et al. 2016; Mohammad and Adamowski 2015; Soomro et al. 2019; Yu 2012). The SCS-CN method is one of the most popular for rainwater flow modeling applied to the design of hydraulic and hydrological simulation in different regions (Alves et al. 2019; Mello et al. 2016; Yu 2012; Banasik et al. 2014; D'Asaro et al. 2014; Kim and Shin 2019; Mishra et al. 2012; Suresh Babu and Mishra 2012; Thong et al. 2019).Because of its simplicity, it was the first tool used to provide input information for practical mechanics designed to reduce soil erosion and sediment transport (Jena et al. 2012). The methodology is based on concepts of surface runoff produced in each precipitation event associated with runoff coefficients. Thus, the SCS-CN methodology depends on soil type, conservation, and coverage.

Design flood events have a specific magnitude-frequency relationship in each location and a sensitivity to the values of the time parameters (Gericke and Smithers 2016). Researchers argue that $75 \%$ of the total error in peak discharge can be attributed to errors in estimating time parameters. Gericke and Smithers (2016) point out that these errors could not only result in design above or below the hydraulic design of structures but also several socioeconomic implications and unviable projects. Thus, watershed response time parameters should be considered as one of the main inputs needed for floods projections.

Following concepts for the parameters that integrate the rain-flow models, Gericke and Smithers $(2016,2014)$ and USDA (2010) highlights the importance of the time of concentration $(t c)$, which can be understood as the time in which the precipitation that falls at the most distant point of the watershed takes until reaching the control section. There are several methods for determining the $t c$ in watersheds. Azizian (2018) suggests the models should be analyzed based on their physical characteristics and compatibility with the studied region.

The concentration time of a watershed, defined as the difference between the beginning of precipitation and the end of runoff, tends to be greater than the concentration time for hydraulic propagation of average flows. Thus, there is a practical uncertainty in the definition when the concentration time affects surface runoff and highlights the importance of determining $t c$ with adequate parameters, among the enormity of equations available at the academy. The concentration time can be determined by means of floats and hydro metering equipment such as windlass or by hypothetical and theoretical analyzes by tracing the unit hydrograph, with empirical or summation equations of transit times, although some methods can overestimate the concentration time with lower flow rates (AZIZIAN 2018).

In this context, this study aimed to analyze the hydrological behavior of the Ribeirão do Suru hydrographic watershed and the effect of increasing waterproofing. The correlation was established between the variation of runoff coefficients $(C N)$, modifications of the recurrence periods $(T)$, and through different methodologies of the time of concentration.

\section{Materials and methods}

\section{Study area}

The Ribeirão do Suru watershed (Fig. 1) is a tributary of the Tietê River and is located in Santana de Parnaíba, São Paulo, Brazil between the coordinates (E 46.997; S 23.404.); (E 46,947.00; S 23,404); (E 446,947; S 23,427); (E 46,997; $\mathrm{S} 23,427)$, with its control section located at the coordinates (E: 299,560.00; S 7406,760.00). With an altimetric gradient of $700 \mathrm{~m}$ to $1041 \mathrm{~m}$, the average annual rainfall corresponds to $1386 \mathrm{~mm}$ (Climate-data 2020). According to the Pluviometric Post of the Department of Water and Electricity, annual data from 1956 to 2016 indicate that the period of water scarcity occurs in the coldest months (July and 


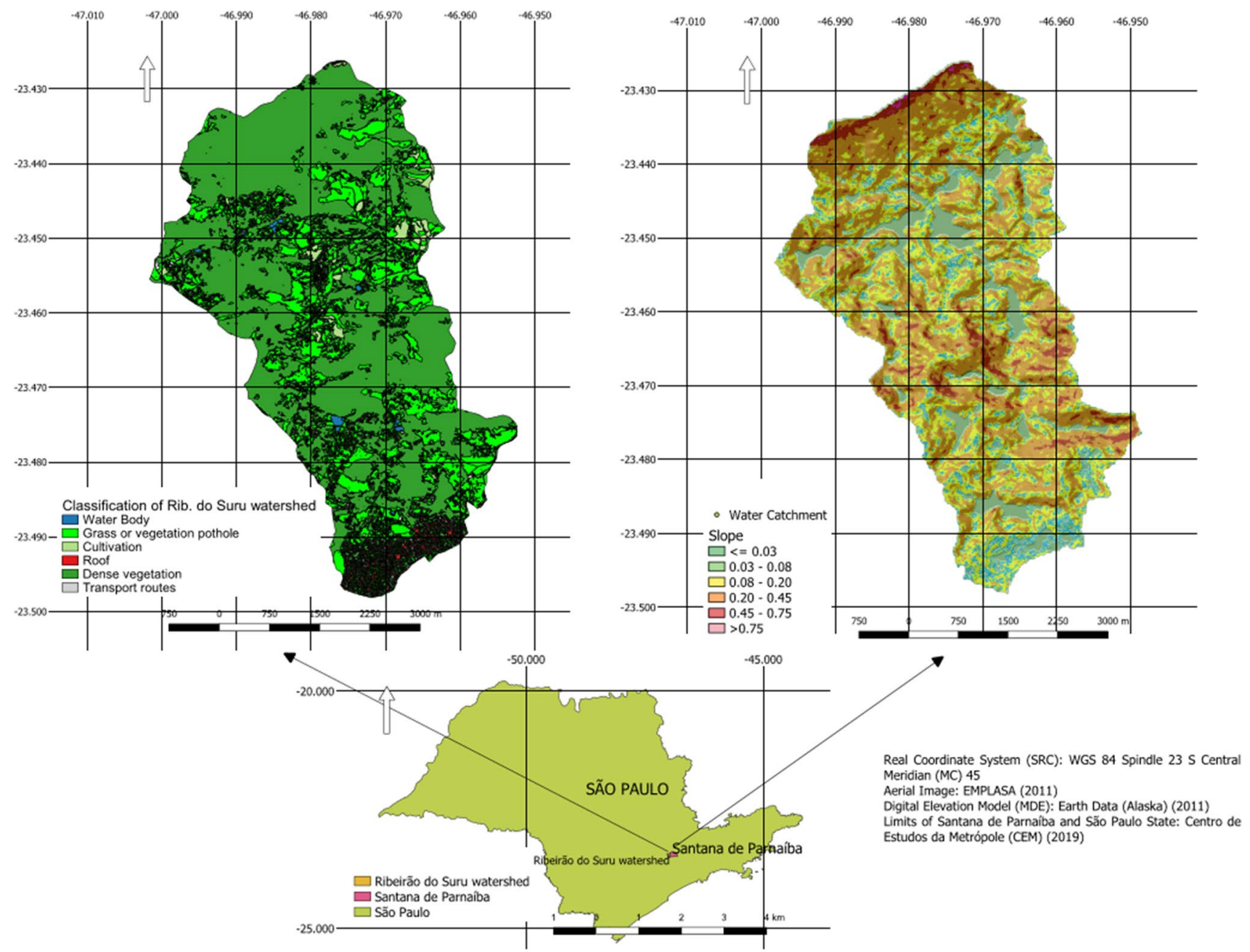

Fig. 1 Land use and occupation and slope, Ribeirão do Suru watershed, Santana do Parnaíba, SP. 2018. Source Yogi (2018)

August). The minimum temperatures occur in June-September, and maximum in December-February, with an annual average of $21.3^{\circ} \mathrm{C}$. The climate is warm and temperate, classified as Cfb (Dubreuil et al. 2019).

The delimitation of the watershed, as well as other physical parameters, were obtained by the elaboration of a Digital Elevation Model (MDE) from satellite images provided by the Space Shuttle Radar Topographic Mission (SRTM) and extracted from the United States of Geological Survey (USGS, 2019) with a spatial resolution of $30 \mathrm{~m}$. The information was processed in QGIS 2.18 (Las Palmas), with the TAUDEM extension.

For this purpose, the spurious pixels were eliminated by filling the depressions and peaks of the different MDE, which could imply the indication of interruption of the water flow. TAUDEM made it possible to obtain matrix data to delimit the contribution and slope watershed, and its threshold was defined by the municipality's vector layer (CEM 2020). The hydrographic grid was determined with the aid of the slope orientation map and, at the same time, vectors were edited that allowed the determination of parameters for the adopted rainfall model, area, and perimeter.

The watershed comprehends a protected region, divided into population densities, diversified uses, and residential settlements with low occupation density (Santana do Parnaíba 2013). The characterization of the watershed was based on the drainage area, river depth, hydrographic profile, transversal representation of the slope, and land use. Five classes were detected: dense vegetation $(0.39 \%)$, water $(2.90 \%)$, grass vegetation (67.55\%), cultivation $(23.50 \%)$ and urban areas $(5.66 \%)$ (Yogi 2018) (Fig. 1). This information was used to obtaining the necessary parameters to achieve the objective of this study. 


\section{Curve number}

The Curve Number $(C N)$ of rain models by the USDA (1986) variates according to the soil type and occupation. Consequently, the use and occupation in urban areas, residential, commercial, and industrial areas in the watershed were established. The determined $C N$ was used by the subdivision of the watershed, considering the hydrogeological group from A to D (Table 1) and the selection of its impermeable areas in surveys of uses verified by Yogi (2018) (Tables 2 and 3) and images from EMPLASA (2011). Thus, for the soils of the Ribeirão do Suru watershed, the $\mathrm{CN}$ was used by (Eq. 1):

$C N=\frac{C N_{1} \times A_{1}+C N_{2} \times A_{2}+C N_{3} \times A_{3+} C N_{4} \times A_{4+} \ldots C N_{i} \times A_{i}}{A_{1}+A_{2}+A_{3}+A_{4} \ldots A_{i}}$

where $C N=$ Curve Number according to the land use classificated in Tables 2 and 3;An=Subdivision of contribution areas.

The soil classification applied was from EMBRAPA (2006). According to Rosa (2020), information on soils in Brazil is limited. However, Pompermayer (2013) recognizes

Table 1 Classification of soil hydrogeological groups (Canholi 2014)

\begin{tabular}{ll}
\hline Soil group & Characteristics \\
\hline A & Sand and deep gravel $(\mathrm{h}>1.50 \mathrm{~m})$, very permeable, with a high infiltration rate, even when saturated. Clay content up to $10 \%$. \\
B & Sandy soils, shallow $(\mathrm{h}<1.50 \mathrm{~m})$ and permeable. Clay content between $10 \%$ and $20 \%$. \\
C & Shallow soils with subsurface layers that prevent downward flow of water. Clay content between $20 \%$ and $30 \%$. \\
D & Soils with high water table, with clay layers close to the surface, or shallow soils over impermeable layers. Clay content above $30 \%$. \\
\hline
\end{tabular}

Table 2 Values of $C N$ for vegetated areas. Adapted from USDA (1986)

\begin{tabular}{|c|c|c|c|c|c|}
\hline \multirow[t]{2}{*}{ Land use } & \multirow[t]{2}{*}{ Surface } & \multicolumn{4}{|c|}{ Soil type } \\
\hline & & A & B & $\mathrm{C}$ & $\mathrm{D}$ \\
\hline \multirow[t]{2}{*}{ Plowed soil } & Straight grooves & 77 & 86 & 91 & 94 \\
\hline & Straight rows & 70 & 80 & 87 & 90 \\
\hline \multirow[t]{3}{*}{ Regular plantings } & Contour lines & 67 & 77 & 83 & 87 \\
\hline & Level terracing & 64 & 76 & 84 & 88 \\
\hline & Straight rows & 64 & 76 & 84 & 88 \\
\hline \multirow[t]{3}{*}{ Cereal plantations } & Contour lines & 62 & 74 & 82 & 85 \\
\hline & Level terracing & 60 & 71 & 79 & 82 \\
\hline & Straight rows & 62 & 75 & 83 & 87 \\
\hline \multirow[t]{5}{*}{ Vegetable plantations } & Contour lines & 60 & 72 & 81 & 84 \\
\hline & Level terracing & 57 & 70 & 78 & 89 \\
\hline & Poor & 68 & 79 & 86 & 89 \\
\hline & Normal & 49 & 69 & 79 & 94 \\
\hline & Good & 39 & 61 & 74 & 80 \\
\hline \multirow[t]{3}{*}{ Grasslands } & Contour lines - poor & 47 & 67 & 81 & 88 \\
\hline & Contour lines- normal & 25 & 59 & 75 & 83 \\
\hline & Contour lines- good & 06 & 35 & 70 & 79 \\
\hline \multirow[t]{4}{*}{ Permanent fields } & Normal & 30 & 58 & 71 & 78 \\
\hline & Sparse, low perspiration & 45 & 66 & 77 & 83 \\
\hline & Normal & 36 & 60 & 73 & 79 \\
\hline & Dense, high perspiration & 25 & 55 & 70 & 77 \\
\hline \multirow[t]{3}{*}{ Country houses Unpaved roads } & Normal & 56 & 75 & 86 & 91 \\
\hline & $\mathrm{Bad}$ & 72 & 82 & 87 & 89 \\
\hline & Hard surface & 74 & 84 & 90 & 92 \\
\hline \multirow[t]{4}{*}{ Forests } & Very sparse, low perspiration & 56 & 75 & 86 & 91 \\
\hline & Sparse & 46 & 68 & 78 & 84 \\
\hline & Dense, high perspiration & 26 & 52 & 62 & 69 \\
\hline & Normal & 36 & 60 & 70 & 76 \\
\hline
\end{tabular}


Table 3 Values of $C N$ for urban areas. Adapted from USDA (1986)

\begin{tabular}{|c|c|c|c|c|c|}
\hline \multirow[t]{2}{*}{ Land use and occupation } & & \multicolumn{4}{|c|}{ Soil type } \\
\hline & & A & B & $\mathrm{C}$ & $\mathrm{D}$ \\
\hline Cultivated areas without soil conservation & & 72 & 81 & 88 & 91 \\
\hline Cultivated areas with soil conservation & & 62 & 71 & 78 & 81 \\
\hline Pastures or land in poor condition & & 68 & 79 & 86 & 89 \\
\hline Vacant land in good condition & & 39 & 61 & 74 & 80 \\
\hline Meadow in good condition & & 30 & 58 & 71 & 78 \\
\hline Woods or areas with poor coverage & & 45 & 66 & 77 & 83 \\
\hline Forests with good cover & & 25 & 55 & 70 & 77 \\
\hline With grass in more than $75 \%$ of the area & & 39 & 61 & 74 & 80 \\
\hline With grass from $50 \%$ to $75 \%$ of the area & & 49 & 69 & 79 & 84 \\
\hline Commercial and office areas & & 89 & 92 & 94 & 95 \\
\hline \multicolumn{6}{|l|}{ Residential areas } \\
\hline Lot $\left(\mathrm{m}^{2}\right)$ & $\begin{array}{l}\text { Impermeable } \\
\text { medium }(\%)\end{array}$ & & & & \\
\hline$<500$ & 65 & 77 & 85 & 90 & 92 \\
\hline 1000 & 38 & 61 & 75 & 83 & 87 \\
\hline 1300 & 30 & 57 & 72 & 81 & 86 \\
\hline 2000 & 25 & 54 & 70 & 80 & 85 \\
\hline 4000 & 20 & 61 & 68 & 79 & 84 \\
\hline Parking lots, roofs, viaduct and others & & 98 & 98 & 98 & 98 \\
\hline \multicolumn{6}{|l|}{ Streets and roads } \\
\hline Asphalt with stormwater drainage & & 98 & 98 & 98 & 98 \\
\hline Paving stone & & 79 & 85 & 89 & 91 \\
\hline Soil & & 72 & 82 & 87 & 89 \\
\hline
\end{tabular}

$* 1$ medium flow condition has Initial Abstraction $=0.2 \mathrm{~S}$. $* 2$ The average percentage waterproof area showed was used to develop the composite CNs. Other assumptions are as follows: the impermeable areas are directly connected to the drainage system, the impermeable areas have a $\mathrm{CN}$ of 98 , and the permeable areas are considered equivalent to the open space with good hydrological conditions. The $\mathrm{CN}$ for other combinations of conditions can be calculated using nomograms that consider the areas that are connected to a drainage system, that do not meet the initial conditions or for disconnection of the impermeable area below $30 \%$ its importance in determining the Curve Number. For higher confidence of the model, the hydrogeological analysis also followed the classificatory survey of Rossi, (2017), de Oliveira et al. (1999) (Tables 2 and 3), and hydrogeological group D. As the level of waterproofing and contribution make the SCS method more complex to estimate the Curve Number, adjustments were needed with the support of USDA (1986) nomograms when the waterproofed area exceeded $30 \%$ of the total drainage area (Fig. 2).

\section{Hydrological data}

Information regarding the intensity and duration of rain was obtained by the São Paulo station-IAG/USP_E3-035R and Department of Water and Electricity (DAEE). The design rainfall $(I(t, T))$ was then determined with the intense rain equation notebook (Eq. 2) from the city of São Paulo (Martinez Junior et al. 2016), as follows:

$$
\begin{aligned}
i(t, T R)= & 32.77 \times(t+20)-0.878+16.10 \times(t+10) \\
& -0.9306 \times\left[-0.4692-0.8474 \ln \ln \left(\frac{T R}{T R-1}\right)\right]
\end{aligned}
$$

where $i=$ Rain intensity, corresponding to duration $t$ and return period $T, \mathrm{~mm} \cdot \mathrm{min}^{-1} ; t=$ Duration of rain, in minutes; $T=$ Return period, in years. The return period $(T)$ fixed in the simulations was 100 years (Daee 2017), a value that is generally applied in macro-drainage projects. The 100-year recurrence period is used to simplify the definition of flooding, which has a statistically $1 \%$ chance of occurring each year. However, it does not mean that the phenomenon cannot occur in consecutive years or even in events of the same year. For this method, the greatest chance of precipitation was verified to surpass the "rain of 100 years" in $0,2,4$, $10,20,50 \%$, respectively, 500, 50, 25, 10, 5, and 2 years. For the time of concentration ( $t c), 11$ methodologies were selected (Table 4), and part of the equations was found to be 
Fig. $2 C N$ calculation method according to impermeable area and connection to the drainage system. Adapted from USDA (1986)

Table 4 Time of concentration (tc) according to different methodologies

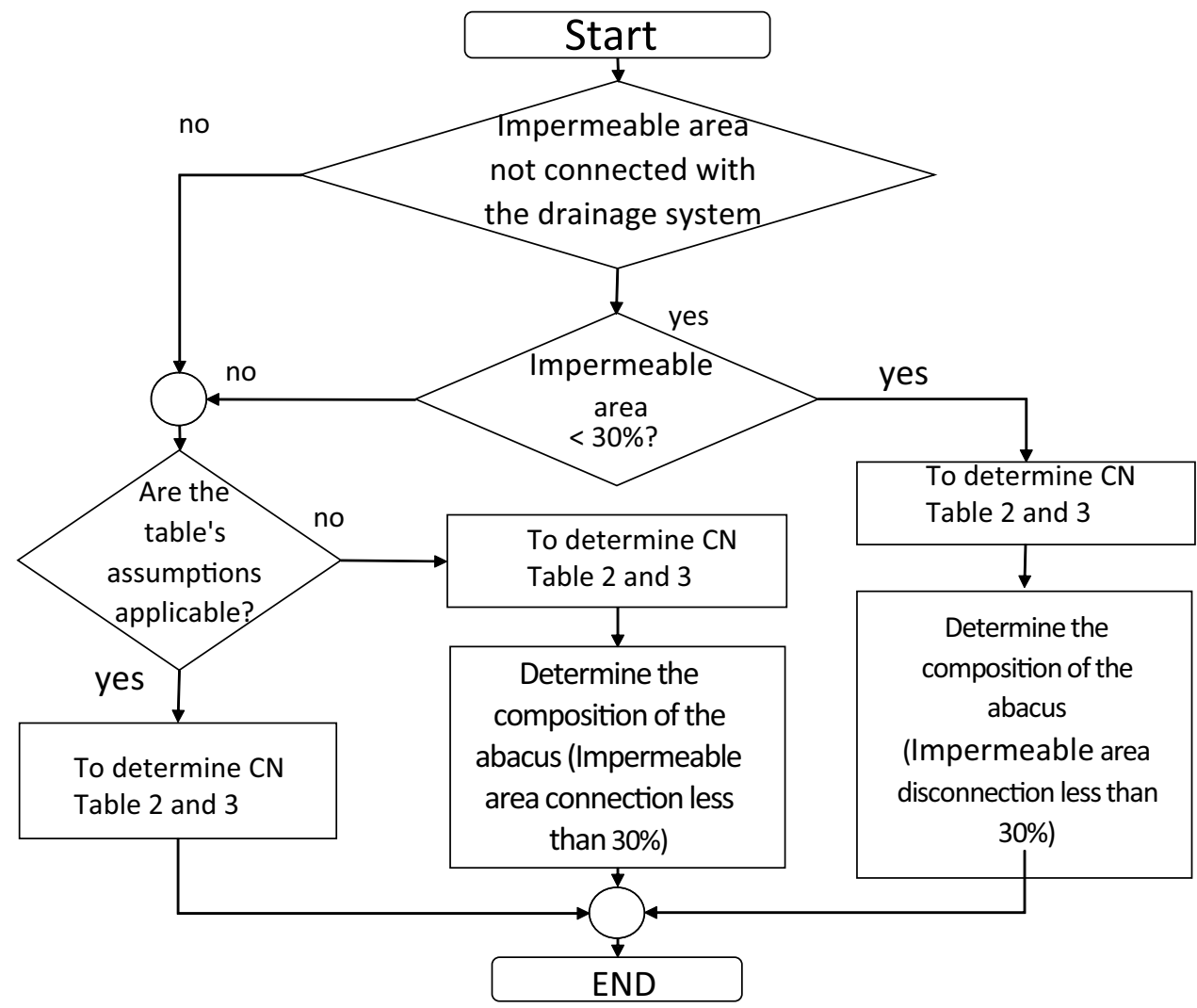

\begin{tabular}{ll}
\hline Method & Equation \\
\hline Bransby Willians (ASDOT 1995) & $t_{c}=14.6 \times L \times A^{-0.1} \times S^{-0.2}$ \\
Dooge (1973) & $t_{c}=21.88 \times A^{0.41} \times S^{-0.17}$ \\
Johnstone and Cross (1949) & $t_{c}=20.17 x\left(\frac{L}{\sqrt{S}}\right)^{0.5}$ \\
Tsuchiya (1978) & $t_{c}=0.83 \times \frac{L}{S^{0.6}}$ (rural watersheds) \\
Soil Conservation Service (1961) & $t_{c}=0.36 x \frac{L}{S^{0.5}}($ urban watersheds) \\
Kirpich (1940) & $t_{c}=342 \times L^{0.8}[(1000 / C N)-9]^{0.7} \times S^{-0.5}$ \\
California Culverts Practice (1960) & $t_{c}=3.989 \times L^{0.77} \times S^{-0.385}$ \\
Federal Aviation Agency (1970) & $t_{c}=57 \times\left(\frac{L^{3}}{H}\right)^{0.385}$ \\
SCS Kinematic Method-SCS (1986) & $t_{c}=22.73 \times(1,1-C) \times L^{0.5} \times S^{0.385}$ \\
DER (2005) & $t_{c}=\frac{1}{60} \times \sum \frac{l_{i}}{v_{i}}$ \\
Tsuchiya (1978) & $t_{c}=85.2 \times\left(\frac{L^{3}}{H}\right)^{0.385}$ \\
& $t_{c}=0.83 x \frac{L}{S^{0.6}}($ rural watersheds) \\
DAEE FCTH (2005) & $t_{c}=0.36 x \frac{L}{S^{0.5}}($ urban watersheds) \\
\end{tabular}

Note tc $(\mathrm{h})=$ time of concentration; $A\left(\mathrm{Km}^{2}\right)=$ area of the watershed; $C(\mathrm{adm})=$ overland flow coefficient of the rational method; $C N(\mathrm{adm})=$ Curve-number parameter of the SCS method; $H(\mathrm{~m})=$ quota difference between the ends of the main water line; $L(\mathrm{Km})=$ length of the main water line; $S(\mathrm{~m} / \mathrm{m})=$ mean steepness (ratio between the mean fall and the $L$ length of the course). Adapted from Almeida et al. (2014), Azizian, (2018), Villegas (2014) 
more appropriate for urban watersheds, while others showed considerable reductions, and therefore more favorable for rural areas.

The $t c$ parameter was determined by the Kirpich (1940), adapted by the Hydraulic Technology Center (CTH), and adequate for small watershed with the predominance of rural uses (USDA 2010). The transformation of precipitation into flow uses hydrogeological parameters, that differ according to the uses. The vegetal cover has a good contribution, while agriculture and impermeable areas induce the increase in the superficial runoff (USDA 1986).

The USDA SCS (1986) conceptually has properties to establish a Unit Hydrograph. The SCS method is simplified by determining the Composite Triangular Hydrogram, following principles of overlapping and proportionality of Synthetic Unit Hydrograms. Through these properties, it is possible to estimate the flow of precipitations with different durations. In this sense, the estimated flow as a function of precipitation was conditioned to the storage capacity of the hydrographic watershed and obtained by a Curve Number$C N$, with the maximum storage (Eq. 3):

$S=\frac{25.400-254 \times C N}{C N}$

where $S=$ Soil infiltration capacity ( $\mathrm{mm}) ; C N=$ curve number (when $C N=100$ the infiltration capacity is zero).

Convert precipitation into flow can be accomplished by storage rates on the ground, usually subdivided in vegetation interception, slope retention, infiltration, or evaporation (Eq. 18) with an abstraction estimated at $I a=0.2 S$ (Canholi 2014):

$P e=\frac{\left(\boldsymbol{P}-\boldsymbol{I}_{\boldsymbol{a}}\right)^{2}}{\boldsymbol{P}-\boldsymbol{I}_{\boldsymbol{a}}+\boldsymbol{S}} \rightarrow P e=\frac{(\boldsymbol{P}-0.2 \times \boldsymbol{S})^{2}}{\boldsymbol{P}+0.8 \times \boldsymbol{S}}$

when $P>0.2 S, P e=4$, and when $P \leq 0.2 S, P e=0 ; P e=$ net precipitation $(\mathrm{mm}) ; I a=$ Initial abstraction $(0.2 \mathrm{~S})(\mathrm{mm})$; $P=$ Precipitation $(\mathrm{mm}) ; S=$ Soil infiltration capacity $(\mathrm{mm})$.

The base time $\left(t_{b}\right)$ was $(1.67+1)$ of the peak time. 20 to $25 \%$ of the $t c$ was adopted for the duration of the rain, with the time recession is $67 \%$ higher than the peak time observed in experimental watersheds (USDA 1986) (Eq. 5).

$t_{b}=2.67 \times t_{p}$

where, $t_{p}=$ Peak time.

Thus, considering the triangular unit hydrograph (USDA 2010), the peak flow $\left(q_{p}\right)$ correlates with a ratio proportional to a precipitation $P$, being:

$q_{p}=\frac{2 \times \boldsymbol{P} \times \boldsymbol{A}}{\boldsymbol{t}_{\boldsymbol{b}}}$ where, $P=$ precipitation $(=1 \mathrm{~mm}) ; A=$ Area $\left(\mathrm{km}^{2}\right) ; t_{p}=$ Peak time.

Through sensitivity analysis, it is possible to identify how each value attributed to the variables of the USDA (1986) rainfall-runoff model interferes with flow estimates. Therefore, the local sensitivity analysis was applied to provide information about the study region and to decrease calibration parameters, eliminating parameters outside the ranges considered most sensitive and most influential. With that, the other variables were sustained, alternating the values obtained by the equations of $t c$ and preserving the other parameters of the diagnosis of land occupation and return periods.

The sensitivity analysis covered the variation of $C N, T$, and $t c$. The 11 equations of time of concentration were evaluated and ranked, pairwise in a linear combination of 110 tests, in the $T$ and $C N$ intervals studied. Finally, the analysis of variance ANOVA and the two-tailed Student's $T$ test with a significance level of $5 \%$ was applied.

\section{Results and discussion}

For the longitudinal profile of Ribeirão do Suru, the values were $S=44.42 \mathrm{~m} . \mathrm{km}^{-1}, L=9.7 \mathrm{~km}, t c=76.24 \mathrm{~min}$, and $i=72.81 \mathrm{~mm} \cdot \mathrm{h}^{-1}$. The uneven relief of Santana de Parnaíba has larger superficial depressions and can retain runoff. This scenario can overcome the estimate retention, implying in a greater damage. According to Pompermayer, (2013), there are no studies in Brazil that confirm the initial abstraction (Ia) of $20 \%$.

In the analysis, the substitution of the $C N$ with an order of magnitude 70 to 90 was simulated, indicating that the flow resulting from the $C N=70$ is $2 \%$ lower than the classified. Thus, $C N\{75 ; 80 ; 85 ; 90\}$ increased, respectively, 3.14 , $5.61,10.90$ and $15.85 \%$ of the flow in the Suru watershed in a 2-h precipitation.

To calculate hydrological runoff parameters such as $C N$, Valle Junior et al. (2019) analyzed different statistical methodologies based on rainfall data in Campo Grande-Mato Grosso do Sul, Brazil. They compared five different USDA CNs (1986), by the geometric, arithmetic, median, and leastsquares adjustment linear through rainfall events. During inconsistencies, the authors found that there is a significant decrease in the performance of the SCS method by USDA (1986) in more forested areas, which did not bring good correlations between precipitation and $C N$. Uwizeyimana et al. (2019) performed the classification of land use and slope of a watershed in Rwanda, where they found an increase in the runoff in dry soil environments, being more expressive in high slopes. 
Although simulation of parameters was not carried out on different dates to verify the evolution of soil sealing in the watershed, it was verified how the process of occupation and use of land could be affected with $C N$ in increasing order (Fig. 3). For the hydrogeological grouping, adopting the most critical situation, the hypothetical scenario indicated an increase of $15.85 \%$ in the runoff when comparing with $C N=73.1$ and estimated $C N=90$.

From the five hypothetical situations of land use and occupation with the $C N$ from 70 to 90 and in intervals of
5 , the variation of the precipitation in function of $\mathrm{T}$ for 2 , $5,10,25,50,100$, and 500 made it possible to obtain the concentration time by the 11 methods. 132 maximum flow hydrographs were obtained and the most representative for the standard equation with the 100-year return period and $C N$, determined according to the watershed uses, illustrate the variations of $t c, T$ and $C N$ (Fig. 4). Thus, the sensibility analysis using the 11 concentration time methods returned guiding values from the formulas in Table 4 and presented in Table 5.
Fig. 3 Unit hydrograph of the runoff sensitivity analysis according to $\mathrm{CN}$ (Peak value) for $\operatorname{Tr}=1.30 \mathrm{~h}$, Ribeirao do suru watershed. Santana de Parnaiba, SP, Brazil. Source Author (2020)

Fig. 4 Unit hydrograph of the flow sensitivity analysis according to the tc. Ribeirão do Suru watershed, Santana de Parnaíba, SP. Source Author (2020)
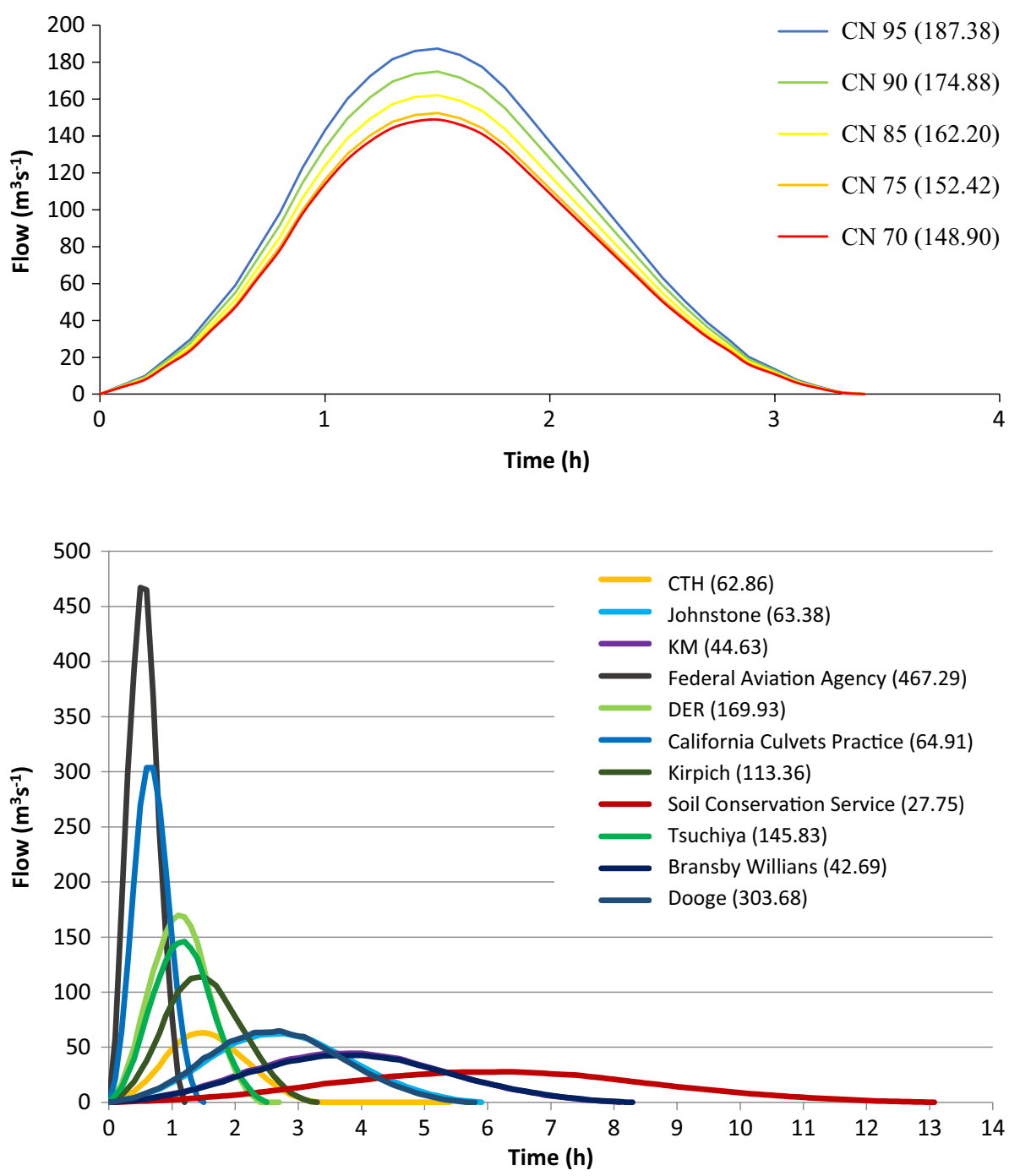

Table 5 Time of concentration ( $t c$ ) according to different methodologies

\begin{tabular}{|c|c|c|c|c|c|c|c|c|c|c|c|}
\hline Method & Bransby Willians & Dooge & Johnstone & Tsuchiya & $\begin{array}{l}\text { Soil Con- } \\
\text { servation } \\
\text { Service }\end{array}$ & Kirpich & $\begin{array}{l}\text { California } \\
\text { Culvers } \\
\text { Practice }\end{array}$ & DER & $\begin{array}{l}\text { Federal } \\
\text { Aviation } \\
\text { Agency }\end{array}$ & KM-SCS & $\mathrm{CTH}$ \\
\hline $\min$ & 194.4 & 129.8 & 137.3 & 52.6 & 296.6 & 76.5 & 31.94 & 47.7 & 18.3 & 183. & 76.3 \\
\hline $\mathrm{h}$ & 3.2 & 2.16 & 2.23 & 0.9 & 4.9 & 1.3 & 0.5 & 0.8 & 0.3 & 3.1 & 1.3 \\
\hline
\end{tabular}


Souza et al. (2018) highlights the importance of appropriating physiographic information from hydrographic watersheds. According to the authors, only California Culvets Practice and Kirpich had all the criteria for applying the $t c$ for rural areas, small watersheds, smooth slope, and length of thalweg smaller than $10 \mathrm{~km}$. On the other hand, Ramos et al. (2017) estimated the $t c$ by different methods in the watershed of approximately $270 \mathrm{~m}^{2}$ with urban characteristics and demonstrated that the concentration time using the Kirpich formula is 55\% less than the time given by SCS Lag. The authors simulated scenarios with the watershed for higher soil sealing rates indicating an increase in the flow of $71 \%\left(0.67 \mathrm{~m}^{3} . \mathrm{s}^{-1}\right)$ compared to the initial conditions using the average $t c$, more than $20 \%$ (12 min) of Kirpich and less than 20\% SCS Lag (20 min).

Kirpich formula must be used with attention in urban watersheds (Chow et al. 1988). According to the recommendations of the Department of Highways (DER) of Santana de Parnaíba (2013), this tc methodology should only be used in small and medium watersheds and is limited to 10-min for infrastructure works. The methodologies of SCS, Dooge, Tsuchiya, and Johnstone have parameters related to occupation and are compatible with rural and green areas. Tsuchiya can be used both in urban and rural watersheds, while the Federal Aviation Agency had the predominant used in urban areas that requires a fast runoff (Souza et al. 2018).

da Silveira (2005) demonstrated the application of several empirical formulas of the $t c$ that depend only on the $L$ and $S$ on a small urban watershed. There was a strong similarity of $t c$ with land use and occupation, except for Johnstone, which brought results closer to the conditions of the experimental watersheds. The Federal Aviation Agency and SCS presents other parameters and demonstrated the incidence of absolute and relative minor errors when compared with Kirpich.

However, a trend in small rural watersheds cannot be observed, and formulas that also depended on the drainage area such as the Dooge presented similar values with Johnstone and CTH. The Dooge equation stands out in the estimates of medium watersheds and in channeled rivers, by the Kinematic method the equation considers the sum of the flow in several segments that form the main thalweg (Franco 2004).

De Almeida et al. (2016) found that time of concentration is inversely proportional to the estimated runoff. The Dooge equation had the lowest $t c$ and the highest drained volume, while SCS Lag had the highest $t c$ and the lowest runoff. Part of it can be attributed the dependence of the formulas for the value of $C N$, which indicate the surface conditions of the soil, attributing a greater sensitivity in the determination of $t c$.

In the Suru watershed, comparing the Recurrence Period of hydraulic macro-drainage works $(T=100$ years $)$ with the others ( $T=2$ to 500 years), it was found that $T$ (Bean et al. 2019; Shao et al. 2018; Teston et al. 2018; Gericke and Smithers 2014; de Parnaíba 2013), respectively, trigger $62.33 ; 45.59 ; 34.51 ; 20.56$ and $10.43 \%$ of flow rates below when $T r=100$, while $T=500$ resulted in an increase of $23.51 \%$ (Fig. 5). Thus, it is noted that the equation adopted for SCS-CN is more sensitive to the Recurrence Period (T) than can be observed in the analysis in $C N$.

Notably, certain precautions must be taken in estimating runoff with the use of recurrence periods in the referred rain-flow model. The critical rains from the micro-drainage project are chosen based on economic criteria, with the usual 5-10-year and probable flood not bringing significant losses (Bohnenberger et al. 2019). For projects in urban areas or economic importance, Ward et al. (2013) indicate that the longer the return period, the lower the probability that a flood event will occur. However, Oleson (2015) points out that in a return period used in emergency situations, recurrence time is seen as absolute data instead of representing averages between consecutive events of a magnitude similar. This scenario triggers misinterpretations as the probability
Fig. 5 Unit hydrograph of the sensitivity analysis according to the Recurrence Period $(\mathrm{T}=1.30 \mathrm{~h}$ ), Ribeirao do Suru watershed, Santana do Parnaiba, SP, Brazil. Source Author (2018)
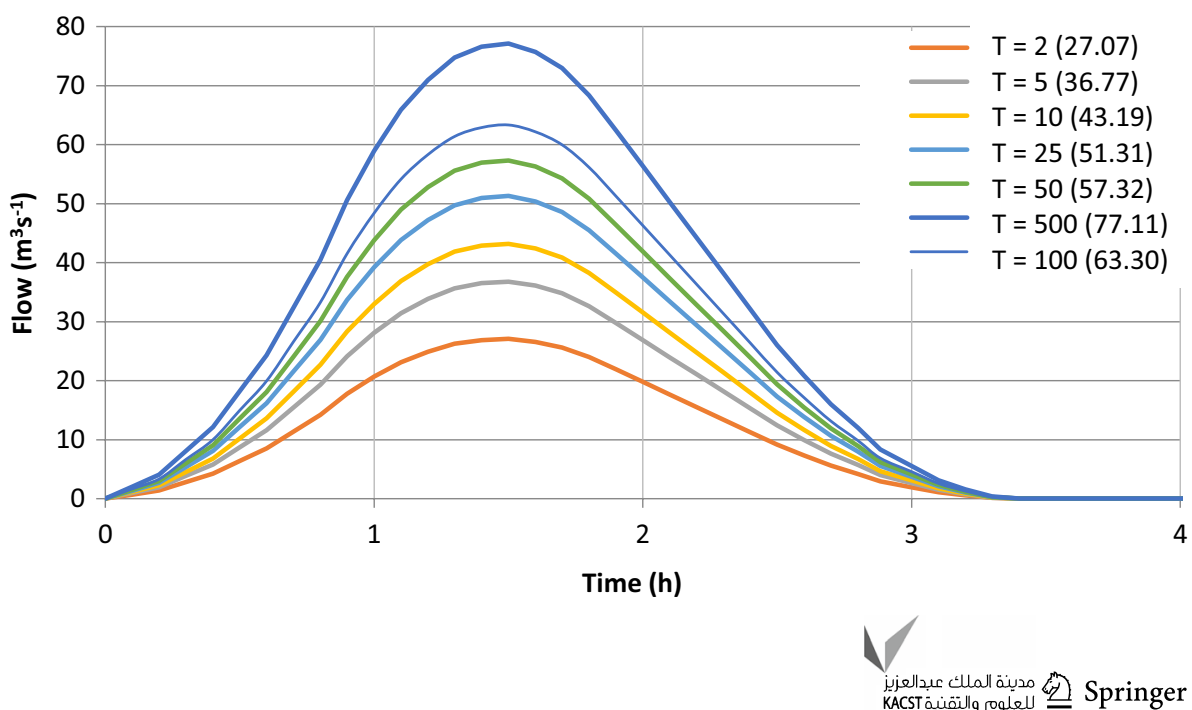
of the precipitations that overcome a catastrophic event of 100 years.

Bohnenberger et al. (2019) indicate that residential, commercial, public services, airports, and high-traffic arteries are dimensioned with the return period of 2-5-10years, while De Almeida et al. $(2016,2016)$ recommends macro-drainage, commercial areas, residential and of specific importance vary between 50, 100 and 500 years.

In Student's T tests and Analysis of Variance (ANOVA) with a significance level of 5\%, both peer and ANOVA assessments, CN sensitivity was shown to be poorly matched, except for Bransby Willians pairs with Kinematic Method, Dooge with Johnstone and CTH with Tsuchyia, the pairs showed degrees of correlation below 59\% (Table 6). The largest deviations were observed as the hypothetical situations were tested with the increase in $C N$, which represent the highest degrees of soil sealing. In contrast, the recurrence period Sensitivity ANOVA, showed a good correlation between the $t c$ methods, excluding the
CTH correlation with Kirpich, since the CTH method is an adaptation of Kirpich.

The greatest correlation was observed in Jonhstone with Dooge (90\%), followed by the Kinematic Method with the Soil Conservation Service Method (83\%) and with Dodge (74\%) (Table 7). This fact shows that the model is more sensitive to changes in land use and occupation than changes in the Recurrence Period.

To understand the hydrological behavior of seasonal changes in agricultural uses in twelve scenarios, de Aguiar et al. (2019) observed a correspondence with acceptance above the 5\% significance level adopted and for the repetitions of the return period, in seven blocks, [2, 5, 10, 25, 50, 100 and 200]. On the other hand, when analyzing seasonally the increase in precipitation, they obtained a rejection in two months that presented high potentials of runoff and precipitation below the annual average.

In the Ribeirão do Suru, it is noticed that the attenuation and/or increase in the runoff for changes in the $\mathrm{T}$ are

Table 6 Correlation between NC and Recurrence Period

\begin{tabular}{|c|c|c|c|c|c|c|c|c|c|c|}
\hline Method & SCS & $\begin{array}{l}\text { Bransby } \\
\text { Willians }\end{array}$ & KM & Johnstone & Dooge & Kirpich & Tsuchiya & $\mathrm{CTH}$ & DER & $\begin{array}{l}\text { California } \\
\text { Culverts } \\
\text { Practice }\end{array}$ \\
\hline Bransby Willians & 0.11 & & & & & & & & & \\
\hline KM & 0.08 & 0.84 & & & & & & & & \\
\hline Johnstone & 0.00 & 0.04 & 0.06 & & & & & & & \\
\hline Dooge & 0.00 & 0.02 & 0.03 & 0.73 & & & & & & \\
\hline Kirpich I & 0.00 & 0.00 & 0.00 & 0.00 & 0.00 & & & & & \\
\hline Tsuchiya & 0.00 & 0.00 & 0.00 & 0.00 & 0.00 & 0.00 & & & & \\
\hline CTH & 0.00 & 0.00 & 0.00 & 0.00 & 0.00 & 0.00 & 0.68 & & & \\
\hline DER & 0.00 & 0.00 & 0.00 & 0.00 & 0.00 & 0.00 & 0.01 & 0.03 & & \\
\hline California Culverts Practice & 0.00 & 0.00 & 0.00 & 0.00 & 0.00 & 0.00 & 0.00 & 0.00 & 0.00 & \\
\hline Federal Aviation Agency & 0.00 & 0.00 & 0.00 & 0.00 & 0.00 & 0.00 & 0.00 & 0.00 & 0.00 & 0.00 \\
\hline
\end{tabular}

Table 7 Correlation between the Recurrence Period $(T)$ and the concentration time $(t c)$ methodologies, Ribeirão do Surú watershed, Santana do Parnaíba, SP, Brazil

\begin{tabular}{|c|c|c|c|c|c|c|c|c|c|c|}
\hline Method & SCS & KM & Dooge & Johnstone & $\begin{array}{l}\text { Bransby } \\
\text { Willians }\end{array}$ & Kirpich & CTH & DER & Tsuchiya & $\begin{array}{l}\text { California } \\
\text { Culverts } \\
\text { Practice }\end{array}$ \\
\hline KM & 0.83 & & & & & & & & & \\
\hline Dooge & 0.59 & 0.74 & & & & & & & & \\
\hline Johnstone & 0.50 & 0.65 & 0.90 & & & & & & & \\
\hline Bransby & 0.22 & 0.31 & 0.49 & 0.57 & & & & & & \\
\hline Kirpich & 0.11 & 0.16 & 0.28 & 0.34 & 0.70 & & & & & \\
\hline $\mathrm{CTH}$ & 0.09 & 0.13 & 0.24 & 0.29 & 0.63 & 0.92 & & & & \\
\hline DER & 0.00 & 0.00 & 0.00 & 0.01 & 0.03 & 0.07 & 0.09 & & & \\
\hline Tsuchiya & 0.00 & 0.00 & 0.00 & 0.00 & 0.00 & 0.00 & 0.01 & 0.26 & & \\
\hline California Practice & 0.00 & 0.00 & 0.00 & 0.00 & 0.00 & 0.00 & 0.00 & 0.00 & 0.00 & \\
\hline Federal Agency & 0.00 & 0.00 & 0.00 & 0.00 & 0.00 & 0.00 & 0.00 & 0.00 & 0.00 & 0.00 \\
\hline
\end{tabular}


more expressive than the changes in the $C N$ (Fig. 5). The watershed is protected by law against settlements that are not single-family (de Parnaíba 2013). The analysis of this sensitivity does not have the influence and weight of the different equations for the $t c$, which now can be applied only to areas with high urban density.

The sensitivity analysis of the SCS rainwater discharge model by USDA (1986) showed less variability for parameters arising from surveys and diagnosis of land uses and occupations than strictly temporal parameters. Since the methods applied for determining $C N$ use Remote Sensing classification tools, which are usually expensive and time-consuming processes. The evaluation of temporal parameters has fundamental properties that give more weight to the flow variation. Efforts should be concentrated on the $T$ and $t c$ parameters that are more sensitive and modify the runoff estimates to a most significant degree. This analysis can provide the diagnosis of watersheds, attributing advantages in the more accurate choice of hydrological parameters. In addition, it automates the process allowing more accurate analyzes for drainage studies of watersheds.

\section{Conclusions}

The study was able to analyze the sensitivity in the flow estimation to changes in SCS parameters (recurrence time, time of concentration, and curve number). It was verified the behavior of the flow to the advancement of the land cover, time of the water in the watershed and recurrence period, reinforced by the hypothesis tests and Analysis of Variance. Thus, according to the sensitivity analysis applied to 11 time of concentration equations, it was possible to calculate the surface runoff more accurately over the watershed. It was noted that the attenuation and/or increase in the runoff for the changes in the recurrence period are more expressive than the changes in the $C N$.

The non-sensitive parameters are discarded. $\mathrm{T}$ analysis showed a higher significance than the hypotheses tested in the $C N$ sensitivity analysis, with a good correlation between the $t c$ methods and the most sensitive parameters for the SCS-CN rainfall-runoff model. In the most extreme events, phenomena that are characterized by longer Recurrence Period ( $\mathrm{T}$ ), situations used to calculate runoff, in high precipitation events that attribute risk to the hydrographic basin, for the parameters analyzed for the Suru watershed, among the most sensitive (eliminating parameters with lower degrees of significance), there are better conditions for dimensioning hydraulic works. In these extreme cases, for surfaces with higher $\mathrm{CN}$ indices, stages that scale waterproofing categories in increasing classificatory order, demonstrate that the water precipitated by the surface of the basin would return in the form of runoff in situations closer to reality.
Financial Disclosure statement The author(s) received no specific funding for this work.

\section{Compliance with ethical standards}

Conflict of interest The authors declares that they have no conflict of interest statements.

Open Access This article is licensed under a Creative Commons Attribution 4.0 International License, which permits use, sharing, adaptation, distribution and reproduction in any medium or format, as long as you give appropriate credit to the original author(s) and the source, provide a link to the Creative Commons licence, and indicate if changes were made. The images or other third party material in this article are included in the article's Creative Commons licence, unless indicated otherwise in a credit line to the material. If material is not included in the article's Creative Commons licence and your intended use is not permitted by statutory regulation or exceeds the permitted use, you will need to obtain permission directly from the copyright holder. To view a copy of this licence, visit http://creativecommons.org/licenses/by/4.0/.

\section{References}

Almeida IK, Almeida AK, Anache JAA, Steffen JL, AlvesSobrinho T (2014) Estimation on time of concentration of overland flow in watersheds: a review. Geociencias 33(4):661-671

Alves PL, Formiga KTM, Traldi MAB (2018) Interferências de espécies arbóreas na interceptação das águas pluviais urbanas. Rev Bras Ciências Ambient 47:89-100. https://doi.org/10.5327/z2176 $-947820180214$

Alves GJ, Rogério de Mello C, Beskow S, Junqueira JA, Nearing MA (2019) Assessment of the soil conservation service-curve number method performance in a tropical oxisol watershed. J Soil Water Conserv 74(5):500-512. https://doi.org/10.2489/jswc.74.5.500

ASDOT (1995) Alaska highway drainage manual. In: Alaska state department of transportation. 1st edn, Alaska

Azizian A (2018) Uncertainty analysis of time of concentration equations based on first-order-analysis (FOA) method. Am J Eng Appl Sci 11(1):327-341. https://doi.org/10.3844/ajeassp.2018.327.341

Banasik K, Krajewski A, Sikorska A, Hejduk L (2014) Curve number estimation for a small urban catchment from recorded rainfall-runoff events. Arch Environ Prot 40(3):75-86. https://doi. org/10.2478/aep-2014-0032

Bean E, Lynn PE, Jennison J, Searcy K, Szoka M (2019) Low-impact development \& green infrastructure: pollution reduction guidance for water quality in southeast Florida. Florida Department of Environmental Protection, Florida

Bohnenberger JC, Cesar KML Jr, Calijuri ML (2019) Numerical modeling for the urban drainage gallery systems design. Rev Bras Recur Hidricos. https://doi.org/10.1590/2318-0331.241920180172

Canholi AP (2014) Drenagem urbana e Controle de Erosão., 2nd ed. Oficina de Textos

Chow VT, Maidment DR, Mays L (1988) Applied hydrology. McGrawHill, New York

Climate-data (2020) Clima de Santana do Parnaíba. pp 1-6

D'Asaro F, Grillone G, Hawkins RH (2014) Curve number: empirical evaluation and comparison with curve number handbook tables in sicily. J Hydrol Eng 19(12):04014035. https://doi.org/10.1061/ (ASCE)HE.1943-5584.0000997

da Silveira ALL (2005) Desempenho de Fórmulas de Tempo de Concentração em Bacias Urbanas e Rurais. Rev Bras Recur Hídricos 10(1):5-23. https://doi.org/10.21168/rbrh.v10n1.p5-29

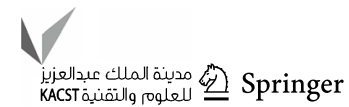


Daee (2017) Instrução Técnica Dpo ${ }^{\circ}{ }^{11}$. São Paulo, Brasil: Departamento de Águas e Energia Elétrica

de Aguiar W, Sampaio SC, Paisani JC, Remor MB, Reis RR (2019) Seasonal dynamics of agricultural soil cover in runoff generation. Eng. Agrícola 39(5):592-599. https://doi.org/10.1590/1809-4430Eng.Agric.v39n5p592-599/2019

De Almeida IK, Steffen JL, Almeida AK, Bacchi CGV, Sobrinho TA (2016) Otimização de parâmetors de modelo hidrológico usando pesquisa harmônica. Geociências 35(1):149-156

de Aragão R, Cruz MAS, de Correia EC, Machado LFM, de Figueiredo EE (2017) Impacto do uso do solo pelo aumento da densidade populacional sobre o escoamento numa área urbana do Nordeste Brasileiro via geotecnologias e modelagem hidrológica. Rev Bras Geogr Física 10(2):543-557

de Carvalho DF, Silva LDB (2016) Hidrologia. UFRJ, Rio de Janeiro

de Oliveira JB, Camargo MN, CalderanoFilho MRB (1999) Mapa pedológico do Estado de São Paulo: legenda expandida. Instituto Agronômico, Campinas

de Parnaíba S (2013) Lei municipal no 3297 , de 8 de agosto de. Brasil 2013:8-10

de Silva MCO, Valverde MC (2017) Cenário futuro da disponibilidade hídrica na Bacia do Alto Tietê. Rev Bras Ciências Ambient 43:114-130. https://doi.org/10.5327/z2176-947820170185

Dooge JCI (1973) Linear theory of hydrologic systems. In: Agricultural research service, 1 st edn

Dubreuil V, Fante KP, Planchon O, Sant'Anna Neto, JL (2019) Climate change evidence in Brazil from Köppen's climate annual types frequency. Int J Climatol 39(3):1446-1456. https://doi.org/10.1002/ joc. 5893

Franco EJ (2004) Dimensionamento de bacias de detenção das águas pluviais com base no método racional. Universidade Federal do Paraná

Gericke OJ, Smithers JC (2014) Review of methods used to estimate catchment response time for the purpose of peak discharge estimation. Hydrol Sci J 59(11):1935-1971. https://doi. org/10.1080/02626667.2013.866712

Gericke OJ, Smithers JC (2016) Are estimates of catchment response time inconsistent as used in current flood hydrology practice in South Africa? J South African Inst Civ Eng 58(1):2-15. https:// doi.org/10.17159/2309-8775/2016/v58n1a1

Jena SK, Tiwari KN, Pandey A, Mishra SK (2012) RS and geographical information system-based evaluation of distributed and composite curve number techniques. J Hydrol Eng 17(11):1278-1286. https://doi.org/10.1061/(ASCE)HE.1943-5584.0000651

Johnstone D, Cross WP (1949) Elements of applied hydrology. 1st edn, Ronald Press, New York

Kim NW, Shin MJ (2019) Curve number estimation of ungauged catchments considering characteristics of rainfall and catchment. KSCE J Civ Eng 23(4):1881-1890. https://doi.org/10.1007/s1220 5-019-0532-1

Kirpich TP (1940) Time of concentration of small agricultural watersheds. J Civ Eng 10(6):362

Leal MS, Tonello KC (2017) Morphometry and land use and cover analysis of Ipaneminha de Baixo watershed. Floresta. https://doi. org/10.5380/rf.v46i3.45809

Machado AR, Mello AV Jr, Wendland EC (2017) Avaliação do modelo J2000/JAMS para modelagem hidrológica em bacias hidrográficas brasileiras. Eng Sanit Ambient 22(2):327-3407. https://doi. org/10.1590/s1413-41522016145177

Martinez Junior F, Magni NLG, Piteri RF, de Toledo SRC (2016) Precipitações intensas do Estado de São Paulo. São Paulo

Mello K, Toppa RH, Cardoso-Leite E (2016) Priority areas for forest conservation in an urban landscape at the transition between Atlantic Forest and Cerrado. Cerne 22(3):277-288. https://doi. org/10.1590/01047760201622032172
Mishra SK, Pandey A, Singh VV (2012) Special issue on soil conservation service curve number (scs-cn) methodology. J Hydrol Eng 17(11):1157. https://doi.org/10.1061/(ASCE)HE.19435584.0000694

Mohammad FS, Adamowski J (2015) Interfacing the geographic information system, remote sensing, and the soil conservation service-curve number method to estimate curve number and runoff volume in the Asir region of Saudi Arabia. Arab J Geosci 8(12):11093-11105. https://doi.org/10.1007/s12517-015-1994-1

Oleson T (2015) The 100-year flood' fallacy: return periods misleading in communication of food risk. Earthmagazine Sci Behind Headl 1:1-2

Pompermayer RC (2013) Modelagem hidrológica técnicas de geoprocessamento aplicadas ao modelo SCS - soil conservation service-Curve number. Universidade Federal de Minas Gerais

Ramos HM, Pérez-Sánchez M, Franco AB, López-Jiménez PA (2017) Urban floods adaptation and sustainable drainage measures. Fluids 2(4):1-18. https://doi.org/10.3390/fluids2040061

Rosa SA, Dalmolin RSD, Moura BJM, Teixeira WG, Alba FJM (2020) Open legacy soil survey data in Brazil: geospatial data quality and how to improve it. Sci Agricola 77(1):e20170430

Rossi M (2017) Mapa pedológico do Estado de São Paulo: revisado e ampliado. Instituto Florestal, Campinas

Santana do Parnaíba (2013) Plano municipal de saneamento: Relatório I Caracterização Geral do Município. Santana doParnaíba. [Online]. Available: https://www.santanadeparnaiba.sp.gov.br/ plano_diretor/relatorios/PMSB/RELATORIOI-Rev01.pdf

Shao G, Guan Y, Zhang D, Yu B, Zhu J (2018) The impacts of climate variability and land use change on streamflow in the Hailiutu River Basin. Water (Switzerland). https://doi.org/10.3390/ w10060814

Soomro AG, Babar MM, Memon AH, Zaidi AZ, Ashraf A, Lund J (2019) Sensitivity of direct runoff to curve number using the SCSCN method. Civ Eng J 5(12):2738-2746. https://doi.org/10.28991 /cej-2019-03091445

Souza JC, dos Reis JAT, Mendonça ASF (2018) Importance of adequate appropriation of physiographic information for concentration times determination. Rev Ambient e Agua 13(4):1-13. https ://doi.org/10.4136/1980-993X

Suresh Babu P, Mishra SK (2012) Improved scs-cn-inspired model. J Hydrol Eng 17(11):1164-1172. https://doi.org/10.1061/(asce) he.1943-5584.0000435

Teston A, Teixeira CA, Ghisi E, Cardoso EB (2018) Impact of rainwater harvesting on the drainage system: Case study of a condominium of houses in Curitiba. Southern Brazil. Water (Switzerland). https://doi.org/10.3390/w10081100

Thong BX, Van Dan N, Trinh NM, Ha NN (2019) Using the method of soil conservation service curve number (SCS-CN) Combined with the Geographic information system (GIS) to estimate the surface runoff on the Co To Island, North Vietnam. Int J Adv Eng Res Sci 6(9):59-75. https://doi.org/10.22161/ijaers.69.6

Tsuchiya A (1978) Evaluation of on-site stormwater detention methods in urbanized area. In: Helliwell PR (ed) Urban storm drainage. London -England, Centech Press, pp 470-478

USDA (1986) Urban Hydrology for Small. Technical release, no 55 (TR-55). soil conservation service. Washigton, DC. [Online]. Available: http://scholar.google.com/scholar?hl=en\&btnG=Searc $\mathrm{h} \& \mathrm{q}=$ intitle:Urban+Hydrology+for+Small+watersheds\#1

USDA (2010) Time of concentration (Chapter 15, Section 4, Part 630) In: Woodward DE, National engineering handbook. USDA NRCS, Washington, DC, pp 1-15

Uwizeyimana D, Mureithi SM, Mvuyekure SM, Karuku G, Kironchi G (2019) Modelling surface runoff using the soil conservation service-curve number method in a drought prone agro-ecological zone in Rwanda. Int Soil Water Conserv Res 7(1):9-17. https:// doi.org/10.1016/j.iswcr.2018.12.001 
Valle LCG Jr, Rodrigues DBB, Oliveira PTS (2019) Initial abstraction ratio and curve number estimation using rainfall and runoff data from a tropical watershed. Rev Bras Recur Hidricos 24(5):1-9. https://doi.org/10.1590/2318-0331.241920170199

Vasconcelos FDM, Mota FS (2020) Gestão ambiental, legislação e os recursos hídricos na cidade de fortaleza (CE). Brasil Rev Bras Ciências Ambient. https://doi.org/10.5327/z2176-947820190579

Villegas P (2014) Tiempo de Concentración de la cuenca. Agua Y SIG. https://www.aguaysig.com/2014/08/tiempo-de-concentrac ion-de-la-cuenca.html. Accessed April 22, 2020

Ward PJ et al (2013) Assessing flood risk at the global scale: model setup, results, and sensitivity. Environ Res Lett 8(4):1. https://doi. org/10.1088/1748-9326/8/4/044019

Yogi F (2018) Parâmetros de estudo em vazão de projeto para renovação de outorga de barramento. 137 f. Dissertação (Mestrado) - Curso de Sustentabilidade na Gestão Ambiental, Centro de
Ciências e Tecnologias Para A Sustentabilidade, Universidade Federal de São Carlos, São Paulo

Yu B (2012) Validation of scs method for runoff estimation. J Hydrol Eng 17(11):1158-1163. https://doi.org/10.1061/(ASCE)HE.19435584.0000484

Zhang H, Jin G, Yu Y (2018) Review of river basinwater resource management in China. Water 10(4):1-14. https://doi.org/10.3390/ w10040425

Publisher's Note Springer Nature remains neutral with regard to jurisdictional claims in published maps and institutional affiliations. 